\title{
sciendo

\section{Implementation of the Smart City Technology for Environmental Protection Management of Cities: The Experience of Russia and Kazakhstan}

\author{
Irina TURGEL ${ }^{1 *}$, Larissa BOZHKO ${ }^{2}$, Elizaveta ULYANOVA ${ }^{1}$, Asset KHABDULLIN ${ }^{2}$ \\ ${ }^{1}$ Ural Federal University, Lenina prosp. 51, Ekaterinburg, Russian Federation \\ ${ }^{2}$ Rudny Industrial Institute, 50 let Oktyabrya street 38, Rudny, Kazakhstan
}

\begin{abstract}
Approaches to the organization of management of environmental protection within the framework of introduction of Smart City technologies are reviewed in this article. For this purpose, a retrospective analysis of transformation of the Smart City notion has been carried out and basic characteristics of a modern smart city interpretation have been distinguished: the use of information technology in all functional areas of the city ecosystem, active involvement of residents in the processes of city management through organization of a system of user services, commitment to sustainable development of a city to the benefit of future generations. In the research process the key factors of the environment pollution in cities were reviewed having identified systemic challenges in the environmental field, which can be solved by introduction of the Smart City technology. For each environmental factor promising technologies of the Smart City system and effects that may be reached by means of their introduction are provided. Analysis of the existing technological solutions of the Smart City made it possible to identify the complex nature of environmental problems of cities, the solution of which requires introduction of smart technologies in all the spheres of functioning of the city. In the practical part of the article smart city's technology development and implementation experience is presented, aimed at environmental protection in the cities of Russia and Kazakhstan. The empirical basis of the analysis is constituted by the results of the studies carried out within the framework of the research work "Enhancement of the State Regulation Policy of Accelerated Clustering of the Industrial Regions" implemented on the grounds of the grant funding of the Ministry of Education and Science of the Republic of Kazakhstan.
\end{abstract}

Keywords - Digital economy; ecology; environmental development; smart city; sustainable smart city

\section{INTRODUCTION}

Current city growth trends, their economic and demographic contribution to the social and economic development of the countries poses new objectives in the field of management of city functioning. According to the data of the World Bank currently $55 \%$ of the planet population lives in cities and the number will exceed $68 \%$ by 2050 . Considering contribution of cities to the current world GDP level - more than $80 \%$, the process of urbanization will enhance sustainable economic growth only under efficient management [1]. On the other hand, the processes of expansion and growing scale of cities may lead to negative

\footnotetext{
* Corresponding author.

E-mail address: i.d.turgel@urfu.ru
}

(C)2019 Irina Turgel, Larissa Bozhko, Elizaveta Ulyanova, Asset Khabdullin.

This is an open access article licensed under the Creative Commons Attribution License (http://creativecommons.org/ licenses/by/4.0), in the manner agreed with Sciendo. 
consequences, called by Vernon Henderson as internal side effects of large cities [2]. For example, the growth of migration to cities leads to excessive density of residents and increase in the urban economy's burden, automobilization leads to transportation problems and technology development to the constant changes in demands from residents and businesses to the quality and capabilities of the urban environment. All this, ultimately, leads to increase in pressure on the environment and environmental problems emergence. According to the International Telecommunication Union, cities account for $75 \%$ of energy consumption and $80 \%$ of $\mathrm{CO}_{2}$ emissions on a global scale, which is one of the biggest problems of environmental policy [3]. Therefore, sustainability and the environment are the most important components of any city's functioning. Current trends in changing principles of the industrial and economic development, widespread introduction of digital technologies in all economic spheres and spheres of life of population create new conditions for gradual review of approaches to managing of city development, which is increasingly built on the advanced technological solutions, digitalization and platformization. The objective consists of the transition of a city management system and several its services and elements into a single integrated digital city ecosystem satisfying the constantly evolving needs of city dwellers, business, authorities and environmental conditions. A current trend is transition to Smart City technologies. And the priorities of sustainable development in the field of territorial management, regulated in international standards and territorial planning documents [4]-[6], make it possible to talk about Smart Sustainable Cities. ITU defines Smart Sustainable City as a result of an innovative city that uses information and communication technologies (ICTs) and other means to improve quality of life, efficiency of urban operation and services, and competitiveness, while ensuring that it meets the needs of present and future generations with respect to economic, social, environmental as well as cultural aspects economic, social, and environmental aspects [3].

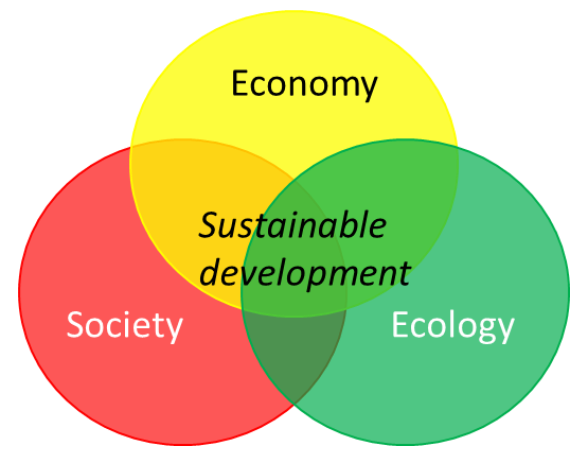

Fig. 1. Sustainable development model.

At the same time, among the key elements of Smart Sustainable Cities development are the following: (1) sustainability and the environment, (2) services and (3) quality of life; and information and communication technologies play the role of a leading tool for such development.

At the moment in Russia and Kazakhstan government programmes in the field of introduction of information and communications digital technologies on the national level have been developed and are functioning. In Russia this is the programme "Digital Economy in the Russian Federation", in Kazakhstan - the Government Programme "Digital Kazakhstan" An indvidual priority in each of these programmes is creation of Smart Cities. 
A Smart City is an integrated concept of territorial development encompassing all its functioning directions, including all industry clusters of the city economy. The concept of such cities implies formation of eco-friendly future of the territory and economic growth, provided as well by the use of intelligent systems of information processing [7]. Therefore, one of the elements of a smart city system is management of the environmental well-being.

\section{TECHNOLOGIES FOR THE MANAGEMENT OF ENVIRONMENTAL Protection as a Smart City Element (Methods and Procedures)}

\subsection{Environmental Challenges in Cities}

Solutions in the field of environmental protection of the city should be aimed primarily at levelling environmental problems of the city. Among key environmental challenges faced by the cities of the post-Soviet area (using Russian and Kazakhstani experience) the most prominent are the following, grouped according to the following aspects:

1. High emissions and waste from the production side. sufficient deterioration level of fixed assets of production enterprises (50.9 \% in the year 2017 in the Russian Federation, $95 \%$ - in Kazakhstan), an insufficient investment level in the infrastructure targeted at the environmental protection and increasing the industrial safety of facilities (only $1 \%$ of all investment in equity capital in the Russian Federation in the year 2017 was targeted at rational environmental management, in Kazakhstan this number constituted $0.99 \%$ ) are the reason of low level of disposal of harmful emissions to the environment (to air, water resources and soil). Thus, according to the data of the Ministry of Natural Resources and Environment of Russia, the level of air pollution is critically high in 20 cities with the population over 4.1 million people [8]. Among these cities there are six cities having enterprises of iron-and-steel and non-ferrous industry, seven — with machine-building plants, four - with forest and wood processing industry. For this reason, in case when large industrial enterprises located in the urban area are one of the principal sources of pollution, a dual mission arises: on the one hand, to reduce negative impact on the environment, on the other hand - to increase the economic operating efficiency of these enterprises;

2. Transport emissions: expansion of housing development and increasing density of city population increase the burden on the transport system of cities, the road network turned out to be unable to perceive the rapidly increased level of motorization, besides the growing number of vehicles significantly contributes to the increase of a negative impact on the ambient air quality in the cities. According to the data of Rosstat in 2017 approximately $45 \%$ of air pollution in Russia occurred due to mobile emission sources (road transport and railway transport), in Kazakhstan - $50 \%$;

3. Accidents of Municipal Economy and Domestic Waste: the level of deterioration of fixed assets in housing and public utilities in 2017 reached on average $45 \%$ in the regions of Russia and in Kazakhstan $-43.9 \%$. Simultaneously, operating costs for the maintenance of existing infrastructure in working order are only growing. Thus, according to Rosstat the share of fully depreciated fixed assets of water collection, purification and distribution comprised around $20 \%$, thermal energy - $13 \%$ [9]. This in turn increases the risk of accidents and losses of energy, which ultimately causes negative impact on the environment and may lead to man-induced situations. Changes in the waste collection and disposal regulations form another challenge for urban and regional governance in Russia 
in the field of the environmental protection. New regulations in the field of industrial and consumption waste handling require rebuilding the entire system, hence timely introduction of new technologies would significantly enable the optimization and efficiency increasing of this type of activities;

4. Increasing people's needs in a favourable urban environment: technology development means that society and business are becoming more demanding on quality and optimality of the city environment. Such demands refer to issues of public amenities, public security, services which can be received in cities. The problem is that most cities are unable to satisfy these needs. Moreover, acceleration of the technological development increases the speed of origination of these demands but due to the limited city budgets territories are unable to keep up with the quality and convenience demands of residents [10]-[12]. A priority project "Development of Comfortable Urban Environment" launched in Russia in 2017 is an attempt to face this challenge [13]. Within the framework of implementation of this project the municipal improvement programme may include various comfortable infrastructure facilities - parks (squares), quays, central streets, cleaning up of dump sites, "hospitality zones" and other facilities. It should be mentioned that most of the enumerated objects are part of the city's nature conservation complex. Most of the abovementioned challenges can be partially or fully resolved through the introduction of smart city technologies.

An additional risk factor in transition of cities to the level of Smart Sustainable Cities is the low level of preparation of cities for Smart City technologies implementation (in terms of infrastructure and management).

5. One of the key challenges faced by the cities introducing elements of digital economy is not as much development and introduction of smart services themselves as poor infrastructure necessary for integration of these services into a single management system. A necessity to build efficient co-operation between city and regional authorities, business representatives, non-governmental organizations and city residents is important. This requires targeted policy for the development of efficient communication with all stakeholders significant for the city development. A serious challenge on the way to introduction of new technologies in the urban space is a lack of relevant legal and regulatory and procedural framework: a smart city concept, its technological components, etc. should be reflected in the legislation [9]. Consideration should also be given to personnel issues related to staff training in information technologies that underlies the smart city.

It should be noted that the specific nature of environmental issues of the city lies in its multidimensionality All the subjects of the city functioning have an impact on its ecological condition.

The main factors of pollution and damage to nature in cities include [14]:

- Emissions from road transport;

- Industrial emissions into the environment and waste;

- Domestic waste and pollution;

- Waste of municipal services;

- Industrial and household noise;

- Radiation and wave effects of communication tools and systems.

The identified environmental factors can be divided into groups according to pollution sources:

- Residents of the city;

- Business (first of all, manufacturing enterprises); 
- Urban economy.

Thus, environmental problems may result from functioning of various spheres of vital activity of the city, for example, inefficient management of urban economy, housing and public utilities, transport system, low level of industrial safety in industrial facilities in the city, problems with improvement, low level of responsibility towards the environment from residents and so on. Therefore, technological solutions for building a smart city system to protect the environment should be used in various industrial complexes of the city, allowing solving problems facing the territory's environmental challenges.

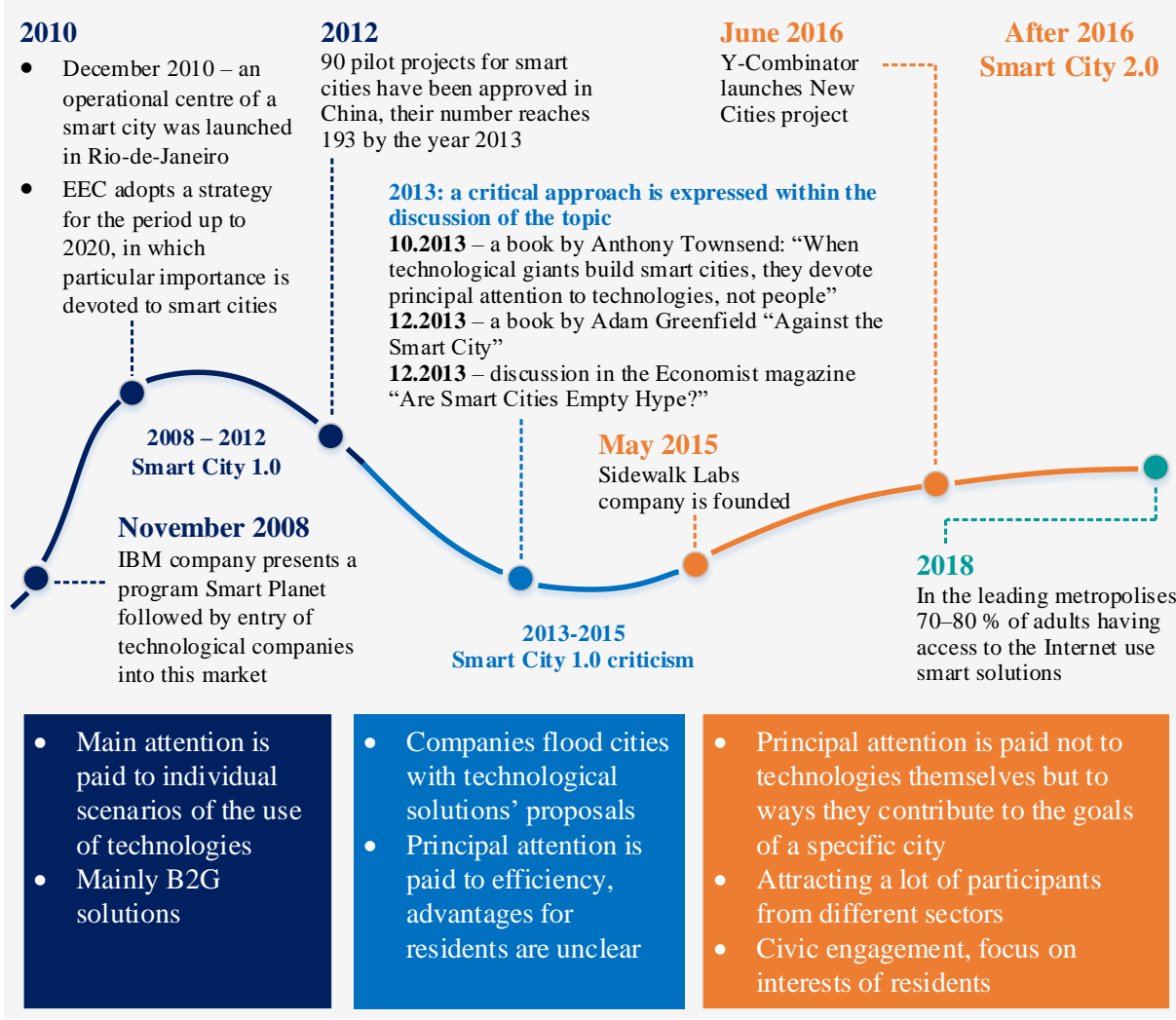

Fig. 2. Environmental protection management technologies as a smart city element (methods and procedures) [32].

Primarily works devoted to the study of Smart City concept and its transformation over time were the methodological basis for the study of the current state and prospects of the Smart City technologies implementation in the field of environmental protection in cities. In this area, Ishida [15], Komninos [16], Van der Meer [17], Sikora-Fernandez [18], Pahomova [19], with reference to the Russian experience - Mavlyutova [20], Merkulov [7], Kamolov [21], Sedov [22] should be noted. Analysis of the existing technological solutions in the field of Smart City and possibilities of their application in various areas of the city's operation are reviewed in Mckinsey Center For Government, The IT-T Focus Group, The Center for Strategic Research "North-West" Foundation, Analytical Center "Expert".

As the use of information and communication technologies is considered in the field of urban ecology, the important aspect of the study were the issues of environmental protection 
and sustainable development, identified in messages and reports of the World Commission on Environment and Development, General Assembly, United Nation, Analytical Centre affiliated to the Government of the Russian Federation [23], international standards for spatial planning, Dolghih [4], Voloshinskaya [24] An important aspect of the study is the theoretical foundations of functioning of the city's environmental protection complex and the ecology of the city. These issues are considered in the works of Girusov [25], Tetyor [26], Gorelova [27], Budreyko [28] and others.

The third block of works on which this study was based are the foundations in the field of strategic planning and management, including territory development (regions and cities), presented in the works of Burak [14], Bariss [29], Vikhansky [30], benchmarking, and principles of a systematic approach.

Data from the Federal State Statistics Service of the Russian Federation and the Committee on Statistics of the Republic of Kazakhstan; State report "On the state and environmental protection of the Russian Federation"; data of analytical reports and ratings were the information base of the study.

Before proceeding to the analysis of Smart City technologies in the field of environmental protection, let's take a closer look at the general concept of the Smart City.

Standard ISO 37120: 2014 "Sustainable development of human settlements - indicators of efficient performance of urban services and quality of life 2.2." The first mention of the smart city concept refers to the beginning of the 2000s [9]. Then the idea was based on the use of IT and corresponding infrastructure to create a virtual city space in the information society [15], [16]. Then, the emphasis in the concept of a smart city shifted towards efficiency improving of city management using information technologies [17]. Subsequently, the focus from information technology shifted towards advanced technologies in general (including IT), consistent with environmental principles and resource saving trends, subject to achievement of planned results [18]. In the period up to 2016, the concept of a smart city began to include an understanding of a smart sustainable city (smart city) [31]. However, at present, according to McKinsey [32], urbanists have come to a new model of a smart city, in which the focus is shifted from the technological component per person, to the active involvement of city residents in its development (Fig. 3). Thus, according to researchers, a modern smart city is not just a municipality with a well-developed technological infrastructure, but a place where human life acquires new quality thanks to smart solutions.

All the existing concepts of "smart city" highlight various aspects of city functioning with the greatest attention from the point of view of digitalization, as a rule, is paid to the information and telecommunications sector, transport system, elements of urban economy (water, energy, heat), management issues. However, this is far from an exhaustive list of functional and technological areas of smart city technologies implementation. In the report of the International Telecommunication Union (the leading UN organization) [33] based on the analysis of successful practices of introducing digital technologies in various cities of the world (including Barcelona, Amsterdam, Hong Kong, Berlin, Dublin, Fujisawa, Dubai) and proposals for technological solutions by the largest corporations there were proposed six functional and technological areas: "smart" lifestyle, "smart" people, "smart" economy, "smart" mobility, "smart" management, and "smart" environment. These areas formed the basis for subsequent formation of a space of services and solutions for smart cities.

It is worth saying that, despite the diversity of functional and technological areas, technologies that affect the state of environmental complex are not only concentrated in the "smart" environment, but are also present in other areas. Therefore, a feature of our research 
is a systematic approach to selection of a complex of Smart City technologies, aimed at reducing the negative environmental factors of cities.

\section{Results}

\subsection{Technologies in the Field of Solving Urban Environmental Problems}

In the course of the work, the existing technological solutions in the field of environmental protection, implemented in cities of the world were analysed and grouped according to the factors of environmental pollution, which are directed to their reducing (Table 1). It should be noted that the table shows the solutions aimed at levelling environmental challenges directly within the framework of economy digitization. In general, the policy to reduce negative impacts and protect the environment can include various measures of a national nature: economic, organizational, infrastructural, educational, etc.

\section{TABle 1. EnVIRONMENTAL Pollution FACTORS AND Possible SOLUTIONS Within DigiTALIZATION OF THE CITY ECOSYSTEM}

\begin{tabular}{|c|c|c|c|c|}
\hline $\begin{array}{l}\text { Ecological } \\
\text { factors }\end{array}$ & Issues & Perspective solutions & Impacts & $\begin{array}{l}\text { Environmental } \\
\text { impact }\end{array}$ \\
\hline \multicolumn{5}{|l|}{ Residents } \\
\hline $\begin{array}{l}\text { Transport } \\
\text { emissions }\end{array}$ & $\begin{array}{l}\text { main source of urban air } \\
\text { pollution; } \\
\text { inconsistency of the } \\
\text { transport system and the } \\
\text { road network with the } \\
\text { current and future level } \\
\text { of development of } \\
\text { motorization }\end{array}$ & $\begin{array}{l}\text { dynamic modelling and } \\
\text { management of traffic flows; } \\
\text { development of public } \\
\text { transport and car sharing }\end{array}$ & $\begin{array}{l}\text { reduction of road } \\
\text { congestion; } \\
\text { reduction of energy } \\
\text { consumption of } \\
\text { vehicles }\end{array}$ & $\begin{array}{l}\text { decrease in } \\
\text { negative } \\
\text { impact on } \\
\text { atmospheric } \\
\text { air }\end{array}$ \\
\hline $\begin{array}{l}\text { Domestic } \\
\text { waste and } \\
\text { pollution }\end{array}$ & $\begin{array}{l}\text { increased waste; } \\
\text { low level of orientation } \\
\text { and responsibility of } \\
\text { residents for the } \\
\text { preservation of the } \\
\text { environment }\end{array}$ & $\begin{array}{l}\text { solutions in the field of } \\
\text { intelligent waste } \\
\text { management (sensors for } \\
\text { controlling the level of } \\
\text { garbage, solutions in the field } \\
\text { of smart sorting and } \\
\text { recycling, smart connected } \\
\text { garbage trucks); } \\
\text { Improving the literacy of } \\
\text { population on the rational use } \\
\text { of waste products }\end{array}$ & $\begin{array}{l}\text { continuous monitoring } \\
\text { in real time due to the } \\
\text { receipt and analysis of } \\
\text { current data on the } \\
\text { status of networks } \\
\text { from sensors; } \\
\text { transition to a more } \\
\text { rational model of } \\
\text { waste management }\end{array}$ & $\begin{array}{l}\text { reduction of } \\
\text { environmenta } \\
\text { l pollution by } \\
\text { improving the } \\
\text { quality of } \\
\text { collection, } \\
\text { transportation } \\
\text { storage and } \\
\text { disposal of } \\
\text { household } \\
\text { waste }\end{array}$ \\
\hline \multicolumn{5}{|l|}{ Business } \\
\hline $\begin{array}{l}\text { Industrial } \\
\text { emissions to } \\
\text { the } \\
\text { environment }\end{array}$ & $\begin{array}{l}\text { low percentage of } \\
\text { disposal of harmful } \\
\text { emissions into the } \\
\text { environment }\end{array}$ & $\begin{array}{l}\text { centralized monitoring } \\
\text { stations, digital surveillance } \\
\text { systems, predictive detection } \\
\text { technologies, as well as } \\
\text { systems that provide a } \\
\text { coordinated response to } \\
\text { situations involving } \\
\text { industrial safety violations; } \\
\text { smart wastewater treatment } \\
\text { systems }\end{array}$ & $\begin{array}{l}\text { calculation of } \\
\text { probability of } \\
\text { accidents at work; } \\
\text { leak detection and } \\
\text { control; } \\
\text { timely response to } \\
\text { pollution emergencies }\end{array}$ & $\begin{array}{l}\text { improving the } \\
\text { quality of the } \\
\text { environment }\end{array}$ \\
\hline $\begin{array}{l}\text { Production } \\
\text { waste }\end{array}$ & $\begin{array}{l}\text { increase in production } \\
\text { waste; }\end{array}$ & $\begin{array}{l}\text { solutions in the field of } \\
\text { intelligent waste } \\
\text { management; }\end{array}$ & $\begin{array}{l}\text { recycling of resources } \\
\text { and waste products }\end{array}$ & $\begin{array}{l}\text { improving the } \\
\text { quality of the } \\
\text { environment }\end{array}$ \\
\hline
\end{tabular}




\begin{tabular}{|c|c|c|c|c|}
\hline & $\begin{array}{l}\text { low level of recycling of } \\
\text { industrial waste }\end{array}$ & $\begin{array}{l}\text { intellectual systems of } \\
\text { production waste sorting; } \\
\text { modern production waste } \\
\text { treatment plants }\end{array}$ & $\begin{array}{l}\text { reduction of } \\
\text { production waste }\end{array}$ & $\begin{array}{l}\text { reduction of } \\
\text { resource } \\
\text { consumption }\end{array}$ \\
\hline $\begin{array}{l}\text { Production } \\
\text { noise }\end{array}$ & \multirow[t]{2}{*}{$\begin{array}{l}\text { noise and wave pollution } \\
\text { of the environment }\end{array}$} & \multirow{2}{*}{$\begin{array}{l}\text { environmental monitoring } \\
\text { systems; } \\
\text { noise control system }\end{array}$} & \multirow{2}{*}{$\begin{array}{l}\text { timely response to } \\
\text { pollution and } \\
\text { emergency situations }\end{array}$} & \multirow{2}{*}{$\begin{array}{l}\text { improving the } \\
\text { quality of } \\
\text { noise } \\
\text { environment }\end{array}$} \\
\hline $\begin{array}{l}\text { Radiation } \\
\text { and wave } \\
\text { effects of } \\
\text { communic } \\
\text { ation } \\
\text { means and } \\
\text { systems }\end{array}$ & & & & \\
\hline \multicolumn{5}{|c|}{ Urban economy } \\
\hline $\begin{array}{l}\text { Waste of } \\
\text { municipal } \\
\text { services } \\
\text { (chemical } \\
\text { reagents, } \\
\text { salt, } \\
\text { bitumen, } \\
\text { etc.) }\end{array}$ & environmental pollution & $\begin{array}{l}\text { smart wastewater treatment } \\
\text { systems; } \\
\text { centralized environmental } \\
\text { monitoring stations; } \\
\text { GIS platforms for monitoring } \\
\text { and maintenance of urban } \\
\text { facilities }\end{array}$ & $\begin{array}{l}\text { timely response to } \\
\text { emergency situations; } \\
\text { quality control of the } \\
\text { functioning of urban } \\
\text { facilities }\end{array}$ & $\begin{array}{l}\text { improving the } \\
\text { quality of the } \\
\text { environment } \\
\text { (air, soil, } \\
\text { water) }\end{array}$ \\
\hline $\begin{array}{l}\text { Emergency } \\
\text { situations } \\
\text { in housing } \\
\text { and } \\
\text { communal } \\
\text { services }\end{array}$ & $\begin{array}{l}\text { loss of resources; } \\
\text { high accident rate of } \\
\text { housing and utilities } \\
\text { infrastructure; } \\
\text { high resource } \\
\text { consumption }\end{array}$ & $\begin{array}{l}\text { intellectual systems of } \\
\text { accounting and remote } \\
\text { control of networks of heat, } \\
\text { water, power supply; } \\
\text { application of solutions in the } \\
\text { field of renewable energy } \\
\text { and intelligent energy } \\
\text { networks; } \\
\text { development of a system of } \\
\text { situational monitoring } \\
\text { centres in the housing and } \\
\text { utilities sector; } \\
\text { intelligent lighting systems; } \\
\text { open consumer services } \\
\text { platforms }\end{array}$ & $\begin{array}{l}\text { improving the } \\
\text { efficiency of detection } \\
\text { of leaks and places of } \\
\text { accidents using the } \\
\text { methods of predictive } \\
\text { analytics }\end{array}$ & $\begin{array}{l}\text { reduction of } \\
\text { loss of } \\
\text { resources; } \\
\text { improving the } \\
\text { efficiency of } \\
\text { resource } \\
\text { consumption }\end{array}$ \\
\hline $\begin{array}{l}\text { Natural } \\
\text { and green } \\
\text { areas }\end{array}$ & $\begin{array}{l}\text { insufficient level of } \\
\text { gardening in cities }\end{array}$ & $\begin{array}{l}\text { systems for monitoring the } \\
\text { state of green spaces and } \\
\text { territories }\end{array}$ & $\begin{array}{l}\text { timely response and } \\
\text { optimization of } \\
\text { processes, landscaping }\end{array}$ & $\begin{array}{l}\text { improving the } \\
\text { quality of the } \\
\text { environment; } \\
\text { increase } \\
\text { comfort of the } \\
\text { urban } \\
\text { environment }\end{array}$ \\
\hline
\end{tabular}

Note: Compiled from materials [9], [21]-[24], [31].

The key components of a smart city system from the technological point of view is data (collected as a result of functioning of elements of a city ecosystem and processed as a result), data processing technologies and decision-making mechanisms. For this reason, the data and software products are the main management instruments of all technological processes [23]. In addition, maximum efficiency of the smart city concept will be achieved if a city is technically fitted, all received and analysed data is open for all members with an acceptable level of their visualization and compatibility of data is observed enabling its integration into a single systemic space. 
Introduction of digitalization elements, aimed at environmental protection within the framework of the Smart City concept is, as a rule, complex and can simultaneously affect various functional areas of the urban ecosystem. Therefore, when developing the Smart City concept in the field of environmental protection for a specific territory, it is necessary to take into account the most problematic areas of urban development and include smart services, which allow for obtaining the greatest synergistic effect from their implementation, including in the area of environmental safety.

\subsection{The Experience of Russia and Kazakhstan in Implementation of Smart City Technologies in the Field of Environmental Protection}

Before describing the experience of introduction of the Smart City concept in the field of the environmental protection in the cities of Russia and Kazakhstan it should be noted that the current character of introduction of smart technologies may be different. According to the analysis of Russia's experience, the computerization projects are most often implemented in the areas of power generation, transport, mobility of citizens, as well as public security. In addition, all projects can be grouped into three categories: local solutions, subsystems and complex solutions [22]:

- Local solutions are most common and in general are localized. Most frequently local solutions involve individual services for users, for example, the Active Citizen (in Russian - “Активный гражданин”) portal in Moscow, as well as projects of intellectualization of individual city infrastructure components - smart pedestrian crossings in Tyumen, smart trams in Samara, etc.;

- Subsystems are more complex and involve higher investment costs and in general are introduced to a lesser extent and gradually as they require significant investment. The most common are safe city projects, for example, the Safe City (in Russian "Безопасный город") system in Penza and Saint-Petersburg, street lighting systems in Yekaterinburg, a project for modernization of the power supply complex of Ufa applying the Smart Grid elements.;

- Integrated solutions are developed on the basis of greenfield projects, in particular, "Innopolis" (Republic of Tatarstan), "Akademichesky" (Yekaterinburg) "SMART City” (Kazan), "Skolkovo" (Moscow Region), "Innograd Yuzhny” (Saint-Petersburg).

We shall review the experience of development and introduction of smart city technologies in the field of environmental protection cases of Sverdlovsk region (Russia) and cities of Kazakhstan.

\subsection{Concept of Introduction of a Smart City System on the Territory of Sverdlovsk Region's Cities}

The Concept of construction on the territory of a constituent entity of the Russian Federation "Smart Region" [25] was developed and approved in the Sverdlovsk Region in 2018 with the aim of achievement of crucial long-term goals of the strategic development of Sverdlovsk Region through the systemic introduction of services and solutions based on the state-of-the-art achievements in the field of digital technologies allowing to solve the most relevant issues of the residents on a new level. The concept is built on the basis of the UNO sustainable development model and is based on approaches to identification of functional and technological areas of development of smart services Six functional areas and more than 130 long-term technological solutions - smart services have been identified for the construction of the Smart Region concept on the territory of the Sverdlovsk Region. Implementation of the 
Concept is planned in close connection with priority projects of the Sverdlovsk Region designated in the Strategy for Socio-Economic Development of the region through the year 2030.

Introduction of the services is divided into three stages:

1. Stage I (2019-2024):

- Services with high speed of effects (quick effects) and low resource consumption,

- Services with low speed of effects (deferred effects) and low resource consumption, the implementation has already begun;

2. Stage II (2025-2030):

- Services with low speed of effects (deferred effects) and low resource consumption, the implementation has not begun yet,

- Services with low speed of effects (deferred effects) and high resource consumption;

3. Stage III (2031-2035):

- Services with high speed of effects (quick effects) and high resource consumption.

A register of smart services aimed at the environmental protection of the Sverdlovsk Region cities in terms of functional and technological spheres is presented in Table 2. 


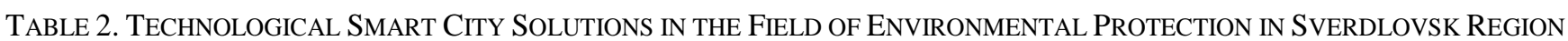

\begin{tabular}{|c|c|c|c|c|c|}
\hline $\begin{array}{l}\text { Functional and } \\
\text { technological } \\
\text { components }\end{array}$ & Sphere of application & Tasks to be solved & Technological solutions/services & $\begin{array}{l}\text { Principal } \\
\text { consumer }\end{array}$ & $\begin{array}{l}\text { Functional and } \\
\text { technological components }\end{array}$ \\
\hline \multirow[t]{6}{*}{$\begin{array}{l}\text { "SMART" } \\
\text { MANAGEMENT }\end{array}$} & \multirow[t]{6}{*}{$\begin{array}{l}\text { Government-to- } \\
\text { Government }\end{array}$} & \multirow[t]{4}{*}{$\begin{array}{l}\text { Optimization of information } \\
\text { exchange between the } \\
\text { structures of local authorities }\end{array}$} & Platforms of inter-agency interaction & $\mathrm{S}$ & \multirow{4}{*}{$\begin{array}{l}\text { Timely response to } \\
\text { problematic situations in } \\
\text { the field of ecology; } \\
\text { Increasing the openness of } \\
\text { access to information on } \\
\text { current environmental } \\
\text { processes; } \\
\text { Simplification of } \\
\text { interagency cooperation; } \\
\text { Improving the efficiency } \\
\text { of implementation of } \\
\text { projects in the field of } \\
\text { environmental protection }\end{array}$} \\
\hline & & & $\begin{array}{l}\text { Single inter-agency repository of reliable, complete } \\
\text { and objective information about environmental and }\end{array}$ & $\mathrm{S}$ & \\
\hline & & & man-induced processes in the regions & & \\
\hline & & & Automation of monitoring and oversight activity & $\mathrm{S}$ & \\
\hline & & \multirow[t]{2}{*}{$\begin{array}{l}\text { Assistance to increasing } \\
\text { operational efficiency of } \\
\text { government agencies }\end{array}$} & $\begin{array}{l}\text { AIS of work coordination of government agencies } \\
\text { of Sverdlovsk Region for ensuring income to the } \\
\text { budget from individual types of taxes and levies }\end{array}$ & $S$ & \\
\hline & & & $\begin{array}{l}\text { Project management in the activity of government } \\
\text { agencies }\end{array}$ & $\mathrm{S}$ & \\
\hline \multirow[t]{3}{*}{$\begin{array}{l}\text { "SMART" } \\
\text { MOBILITY }\end{array}$} & Passenger traffic & $\begin{array}{l}\text { Traffic management of } \\
\text { public transport }\end{array}$ & Remote control of technical condition of vehicles & $\mathrm{S}$ & $\begin{array}{l}\text { Reduction of emissions of } \\
\text { transport into the } \\
\text { atmospheric air due to } \\
\text { optimization of traffic } \\
\text { flows and timely } \\
\text { resolution of problem } \\
\text { situations }\end{array}$ \\
\hline & \multirow[t]{2}{*}{ Road traffic management } & $\begin{array}{l}\text { Securing centralized } \\
\text { management of traffic } \\
\text { regulation systems }\end{array}$ & Situation centres for transport management. & $\mathrm{S}$ & \\
\hline & & Flow of traffic management & $\begin{array}{l}\text { Control and management of objects of the road } \\
\text { infrastructure, including traffic lights and traffic } \\
\text { control lamps }\end{array}$ & $\mathrm{S}$ & \\
\hline
\end{tabular}




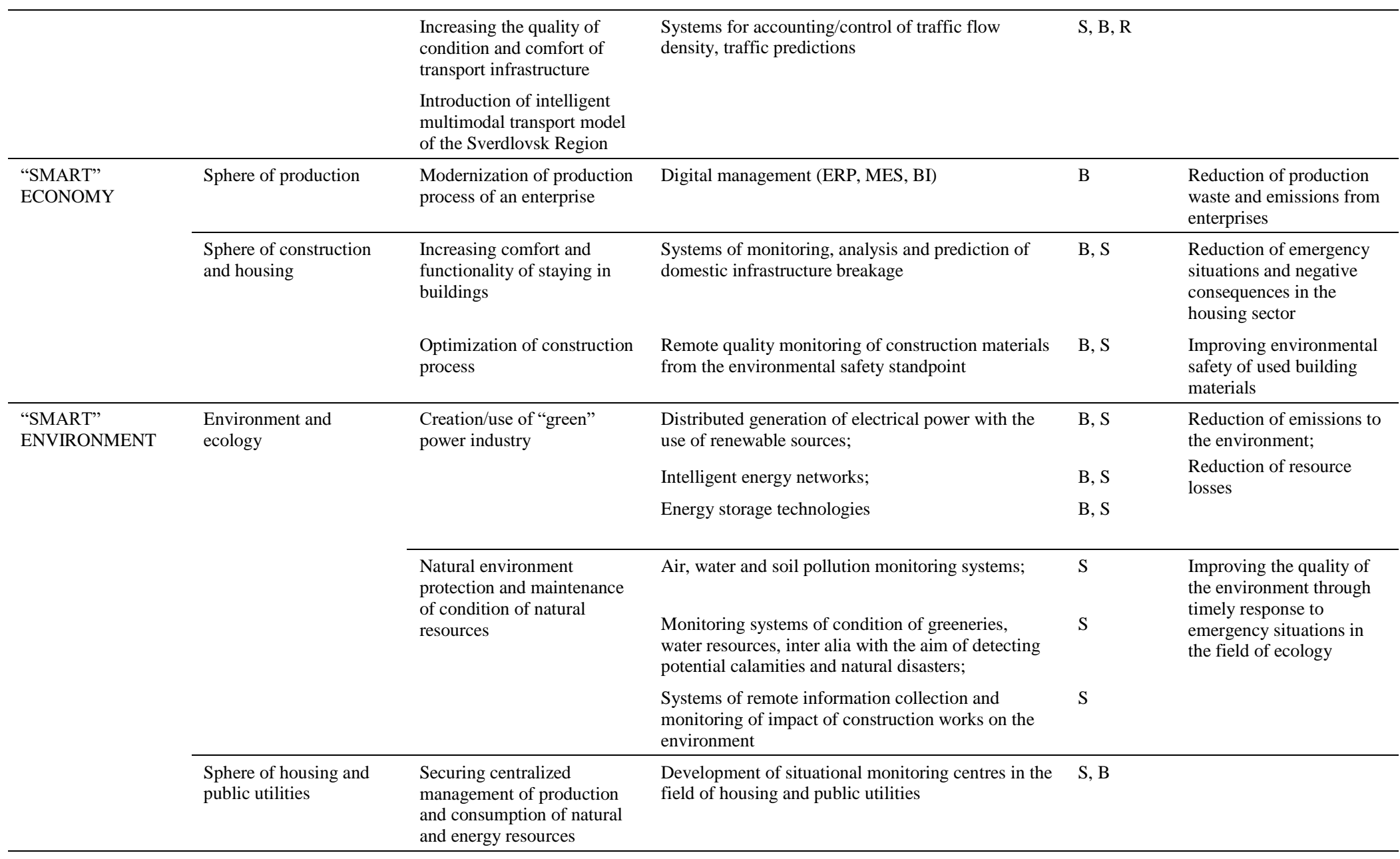


Securing rational consumption of resources

"Smart" external lighting (power LED, motion detectors, lighting intensity regulation systems depending on the environment condition, weather conditions, intensity of other light sources, remote system management, built-in modules wi-fi/Bluetooth, etc.)

Systems of automated information accounting on the consumption of resources in the sphere of housing and public utilities;

Mobile applications for measurement transmission and personal management of volumes of resource consumption

Quality improvement of the housing and public utilities' infrastructure

Systems for monitoring of the condition of the communal infrastructure objects (pavements, pipes, etc.) with the aim of informing public utilities companies about the current condition and timely elimination of public utilities accidents; a webinterface with relevant information about the regional communal infrastructure (electronic models of heat, water supply structures, drainage) applying a single standard

Systems for simulation of power supply (Energy Design Resources)

\begin{tabular}{ll}
\hline Resource recovery & $\begin{array}{l}\text { Optimization of the system } \\
\text { for collection, processing } \\
\text { and disposal of solid } \\
\text { household waste }\end{array}$ \\
\hline
\end{tabular}

\section{Interactive map of dumps}

Intelligent systems of waste sorting (for example, S, BRFID-tags)

Monitoring of occupancy rate of trash cans

Application of the water

reuse system

City environment Systems of remote automated analysis of suitability of the used water resources for their reuse

Waste collection system according to the principle

\section{Optimization of capacity of} vehicles of the public utilities' companies
S

Reduction of resource

losses;

Improving the efficiency

of interaction in the

housing sector

S

$\mathrm{S}, \mathrm{B}, \mathrm{R}$

S

Decrease in accident rate in the sphere of housing and communal services just-in-time

S, B

S, B S

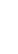

B

\author{
Reduction of \\ environmental pollution; \\ Improving the efficiency \\ of resource use \\ Improving the efficiency \\ of interaction in the \\ housing sector;
}

Reduction of environmental pollution 


\begin{tabular}{|c|c|c|c|c|c|}
\hline & & $\begin{array}{l}\text { Creation of "comfortable" } \\
\text { environment }\end{array}$ & Control system of noise pollution level & $\mathrm{S}$ & $\begin{array}{l}\text { Improving the quality of } \\
\text { the environment }\end{array}$ \\
\hline & & $\begin{array}{l}\text { Improving performance of } \\
\text { quality transformation of the } \\
\text { urban space }\end{array}$ & $\begin{array}{l}\text { Integration of information about projects in the field } \\
\text { of development and reconstruction of the city } \\
\text { infrastructure }\end{array}$ & $\mathrm{S}$ & $\begin{array}{l}\text { Improving the quality and } \\
\text { comfort of the urban } \\
\text { environment }\end{array}$ \\
\hline \multirow[t]{3}{*}{ "SMART" LIVING } & \multirow[t]{3}{*}{ Security of citizens } & \multirow[t]{3}{*}{ Securing industrial safety } & Systems of detection of leaks at enterprises & $\mathrm{B}$ & \multirow{3}{*}{$\begin{array}{l}\text { Reduction of production } \\
\text { waste and environmental } \\
\text { emissions }\end{array}$} \\
\hline & & & $\begin{array}{l}\text { Monitoring of emission of harmful substances by } \\
\text { enterprises }\end{array}$ & B & \\
\hline & & & Systems of prevention of emergencies at enterprises. & $\mathrm{B}$ & \\
\hline \multirow[t]{3}{*}{ "SMART" PEOPLE } & Education system & $\begin{array}{l}\text { Building an information } \\
\text { society }\end{array}$ & $\begin{array}{l}\text { System of general computer literacy within } \\
\text { application of the user services, for example, } \\
\text { application for tracking water consumption in a real } \\
\text { time mode (using smart meters), application for } \\
\text { tracking power consumption in a real time mode } \\
\text { (using smart meters) }\end{array}$ & $\mathrm{S}, \mathrm{R}$ & $\begin{array}{l}\text { Increasing data } \\
\text { transparency in the } \\
\text { housing and utilities } \\
\text { sector; } \\
\text { Improving the efficiency } \\
\text { of interaction with } \\
\text { consumers in the housing } \\
\text { and utilities sector }\end{array}$ \\
\hline & $\begin{array}{l}\text { Inventive activity and } \\
\text { creativity of citizens }\end{array}$ & $\begin{array}{l}\text { Creation of infrastructure for } \\
\text { development in the smart } \\
\text { field }\end{array}$ & $\begin{array}{l}\text { Creation of centres for training in new technologies, } \\
\text { smart-technologies }\end{array}$ & $\mathrm{S}, \mathrm{B}, \mathrm{R}$ & $\begin{array}{l}\text { Development of smart } \\
\text { services in the field of } \\
\text { environmental protection }\end{array}$ \\
\hline & Social activity of citizens & Building a civil society & $\begin{array}{l}\text { Mobile applications of quick reaction (for example, } \\
\text { "People's Control" ("Народный контроль") }\end{array}$ & $\mathrm{S}, \mathrm{B}, \mathrm{R}$ & $\begin{array}{l}\text { Increasing the } \\
\text { involvement of residents } \\
\text { in the field of } \\
\text { environmental protection } \\
\text { of the city }\end{array}$ \\
\hline
\end{tabular}

Note: Compiled on the basis of materials [34]. 
Out of 130 technological services included in the smart region Concept of Sverdlovsk Region 39 affect the state of environment either directly or indirectly.

For the purpose of introduction of the smart city system a special project office has been created in the Sverdlovsk Region.

\subsection{Experience of Introduction of Smart City Elements in the Field of Environmental Protection in the Cities of Kazakhstan}

"Smart cities" direction targeted at introduction of the smart city concept in the cities of Kazakhstan with the aim to increase quality of life and security of city dwellers is implemented in Kazakhstan within the framework of the state programme "Digital Kazakhstan". In 2018 the implementation of the projects Smart Astana and Smart Almaty was begun, pilot projects for testing of individual smart city elements in 17 country regions were launched, as well as a pilot Robopolis project launch was performed on the territory of EXPO. Thus, it is planned to polish the environmental smart city directions in the Akmola and East Kazakhstan regions.

Currently the following stages of introducing a smart city in the cities of Kazakhstan are distinguished:

- 2017 - development of the Smart City concept;

- 2018 - introduction of universal solutions (cloud EDMS, paper free, etc.);

- 2019-2020-introduction of industry-specific solutions (telemedicine, school management systems, etc.);

- 2021-2023 - interaction according to the principle of joint innovations.

In Astana the project "System of Complex Life Support" has been implemented since 2012. Part of these directions refer to the sphere of environmental protection. Segments of creation of a data processing centre, operational management centre and intelligent contact centre are functioning within the framework of the project. Initiatives in the direction of "Smart Street Lighting" [35].

In the city of Akkol of the Akmola Region a pilot project for the introduction of modern technologies Smart City Smart Aqkol [36], in which intelligent systems must ensure efficient functioning of city services, security and comfort of residents, is being implemented. Kazakhtelecom JSC, where the data processing centre has been created, has become its infrastructure operator. The centre implements data collection from all systems of video surveillance, environmental monitoring, control and accounting of energy resources, road traffic management, fire safety operating in the city. Infrastructure of the situation centre allows organizing inter-agency interaction, demonstration of solutions for tactical and strategical city management, including work of public utility companies, aggregation of reliable and timely data about city resources and security.

For the purpose of introduction of information and digital technologies within the framework of the Smart City project infrastructure required for the collection of relevant information about its functioning was created:

- 17.5 thousand $\mathrm{km}$ of fibre optics were laid;

- Power efficient LoRaWAN network was created;

- Public Wi-Fi was created;

- LTE network was modernized;

- An up-to-date digital city map was created, which contains information about buildings and constructions, land plots, engineering and infrastructure networks;

- Approximately 70 CCTV cameras were installed, including on the way into city, in 
schools, other public places and spaces;

- Each house and apartment (up to 6 thousand houses are located in Akkol, of which 90 - blocks of flats) were equipped with modern "smart" detectors and accounting devices (for water, electrical power, heat);

- An intelligent street lighting system has been equipped and for this purpose around 250 lamps were installed which allowed reducing expenses of local government agencies on electricity more than 3 times.

All data from the detectors and equipment come to the Situation Centre where information is collected and analysed (analytics is based on artificial intelligence). While integration of the Smart Aqkol system, with other databases (for example, educational, heath care, tax databases) allows carrying out in-depth analysis of the city life's data, acquiring new knowledge about the current situation and building an efficient system for decision making by city authorities and services.

Almaty has become another example of an efficient introduction of smart city technologies: it ranked first at the European forum of smart cities "Smart city-2018" with implementation of a complex project of the transport system optimization [37].

The complex project of the Almaty transport system reform includes:

- Bus fleet renewal (up to $80 \%$ );

- Construction of a vehicle fleet and plant for production of electric buses of third generation;

- Organization of the first in the country BRT (bus rapid transit) line;

- $110 \mathrm{~km}$ of public transport lanes and one-lane traffic system have been introduced;

- A bike corridor has been created;

- Construction of two metro stations connecting the centre of the city with dormitory suburbs;

- Transactions in public transport have been switched to cashless transfers (over $97 \%$ );

- An automated system of the operations control with a GPS system and video cameras on buses has been introduced, as well as a system of fines for complaints of passengers within subsidizing of carriers;

- A system of photo and video recording of traffic violations is in operation; 709 traffic lanes are controlled;

- All city's underground walkways have been renovated.

It should be noted that in the process of development of approaches to the implementation of the transport reform the city authorities co-operated with the leading international specialists.

\section{Conclusions}

As a result of the conducted research the following conclusion can be made:

1. Modern understanding of the Smart City concept is based not only on a broad-scale introduction of information and communication technologies in all functional spheres of the cities' eco-system. Currently the principles of sustainable development and active involvement of city's residents in common problem solving and development of the city area are at the core of the smart city concept. Importance is being increasingly attached to collaboration of all kinds of all stakeholders (residents, business, public organizations and authorities), while digitalization of all sectors of economy integrated into a single system space and intelligent infrastructure allow managing all city 
functioning processes in a real time mode;

2. The level of development of Smart City technologies in selected cities of Russia and Kazakhstan at the moment is fragmented being represented by local solutions or individual subsystems. Among the key reasons the following can be mentioned:

- An insufficient level of cities' funding for the implementation of development projects, including due to cities' budgeting specifics,

- An insufficient level or lack of a legal and regulatory framework, regulatory procedures, requirements, opportunity for the introduction of digital technologies in the urban economy in relation to several issues,

- Too high depreciation rate of infrastructure, which does not allow for active introduction of new technologies and digital solutions within the framework of the Smart City concept,

- Low level of readiness of technologies for the use in the process of introduction of Smart City elements enabling for efficient integration and processing of data of different urban economy sectors;

3. Smart city elements in the cities of Russia and Kazakhstan are most common in the field of transport system, utilities, power industry and security. Environmental protection projects in general are not emphasised. At the same time the specific of the environmental area lies in its versatility and complexity. Most functional directions of a city "life" directly or indirectly affect the environment therefore introduction of smart technologies in different areas of the city ecosystem one way or another have an impact on the environmental situation in cities, thus forming the synergetic effect;

4. Introduction of smart city technologies in general has a gradual and long-term character. Nevertheless, the effects of the use of smart technologies are complex. Among the principal systemic results, the following are distinguished:

- Resource and cost savings in a long term. - increasing the efficiency of urban governance, possibility timely react to problem situations, as well as improvement of functioning of individual spheres of city ecosystem,

- Increasing security of the city environment through consolidation of various databases in a single system,

- Increasing transparency and observability of the urban economy management processes.

\section{REFERENCES}

[1] The World Bank. Urban Development [Online]. [Accessed 26.02.2019]. Available: http://www.worldbank.org/en/topic/urbandevelopment/overview\#1

[2] Henderson V. Urban primacy, external costs and quality of life. Resource and Energy Economics 2005:24(1-2):95-106. doi:10.1016/S0928-7655(01)00052-5

[3] International Telecommunication Union. Shaping smarter and more sustainable cities striving for sustainable development goals [Online]. [Accessed 14.05.2019]. Available: https://www.itu.int/pub/T-TUT-SSCIOT-2016-1

[4] Dolghih E. I., Antonov E. V. The rating of sustainable development of cities. Energy: economy, technology, ecology 2014:8:53-59.

[5] Our Common Future. Report of the World Commission on Environment and Development [Online]. [Accessed 26.02.2019]. Available: http://www.un.org/ru/ga/pdf/brundtland.pdf

[6] Transforming our world: the 2030 Agenda for Sustainable Development. Resolution adopted by the General $\begin{array}{llll}\text { Assembly } & \text { [Online]. } & \text { 26.02.2019]. } & \text { Available: }\end{array}$ http://www.un.org/ga/search/view_doc.asp?symbol=A/RES/70/1\&Lang=E

[7] Merkulov V., Shemyakina T. Strategies of "Smart Cities" creation and development. Vestnik Universiteta 2018:4:39-42. doi:10.26425/1816-4277-2018-4-39-42 
[8] 20 the most dirty cities of Russia. Vedomosty [Online]. [Accessed 26.02.2019]. Available: https://www.vedomosti.ru/lifestyle/galleries/2017/09/21/734769-20-gryaznih-gorodov

[9] Priority areas for the implementation of smart city technologies in Russian cities [Online]. [Accessed 26.02.2019]. Available: https://www.csr.ru/wp-content/uploads/2018/06/Report-Smart-Cities-WEB.pdf

[10] Naizabekov A., Bozhko L. Future development of cluster initiatives in the Republic of Kazakhstan. Energy Procedia 2018:147:654-659. doi:10.1016/j.egypro.2018.07.085

[11] Bozhko L. Development scenarios for the interregional economic interaction in the context of economy clustering in the Republic of Kazakhstan. Energy Procedia 2018:147:397-401. doi:10.1016/j.egypro.2018.07.109

[12] Turgel I., Bozhko L., Leskova L. State Support of Monotowns in Russia and Kazakhstan: Experience and Problems. Energy Procedia 2016:95:559-563. doi:10.1016/j.egypro.2016.09.085

[13] Passport priority project "Formation of a comfortable urban environment" [Online]. [Accessed 26.02.2019]. Available: http://static.government.ru/media/files/JEnYAAfDkMAyyIAjsAxDzkxXGPuaEJSu.pdf

[14] Burak P. I. Economics and management of a large city. Moscow: Publishing house of the international house in Moscow, 2014.

[15] Ishida T., Isbister K. DigitalCities: Technologies, experiences, and future perspectives. Berlin: Springer-Verlag, 2000.

[16] Komninos N. The Age of Intelligent Cities. Smart environments and innovation-for-all strategies. New York: Routledge, 2015.

[17] Van der Meer A., Van Winden W. E-governance in Cities: A Comparison of Urban Information and Communication Technology Policies. Regional Studies 2003:37(4):407-419. doi:10.1080/0034340032000074433

[18] Sikora-Fernandez D., Stawasz D. The Concept of Smart City in The Theory and Practice of Urban Development Management. Romanian Journal of Regional Science [Online]. [Accessed 24.02.2019]. Available: http://www.rrsa.ro/rjrs/V1015.Sikora.pdf

[19] Pahomova N. B., Richter K. K. Digital economy as an innovation of the 21st century: challenges and chances for sustainable development. Problems of modern economy 2018:66(2).

[20] Mavlyutova G. A., Nozhkina E. B., Altukhov P. L. Sustainable development of digital economy as an element of securing national security of the Russian Federation. Economic security and quality 2018:1(30):19-24.

[21] Kamolov S. G., Korneeva A. M. Future Technologies for Smart Cities. Bulletin of Moscow Region State University. Series: Economics 2018:2:100-114. doi:10.18384/2310-6646-2018-2-100-114.

[22] Sedov A.V., et al. The European Concept of Smart City [Online]. [Accessed 17.05.2019]. Available: https://ssrn.com/abstract=2805441

[23] Analytical Centre affiliated to the Government of the Russian Federation. Report on Human Development in Russia, 2016. Objectives for sustainable development in UN and Russia. Brief Version. 2016:44.

[24] Voloshinskaya A. A., Komarov V. M., Kotsyubinskiy V. A. Contemporary Theories of Sustainable Development: Approaches, Methodology, Practical Recommendations [Online]. [Accessed 17.05.2019]. Available: https://ssrn.com/abstract=2920441

[25] Ecology and environmental economics. Moscow: Eniti, 2010.

[26] Tetior A. N. Ecology of the urban environment. Moscow: Academy, 2013.

[27] Gorelov A. A. Fundamentals of ecology. Moscow: Academy, 2013.

[28] Budreyko E. N. Ecology of cities. Soil, water and air pollution [Online]. [Accessed 05/18/2019] Available: https://www.portal-slovo.ru/impressionism/41495.php

[29] Bariss U., et al. System Dynamics Modeling of Households' Electricity Consumption and Cost-Income Ratio: A Case Study of Latvia. Environmental and Climate Technologies 2017:20:36-50. doi:10.1515/rtuect-2017-0009

[30] Vikhansky O. S. Strategic Management: Tutorial. 2nd ed. Moscow: Gardarik, 1998:296.

[31] Smart cities and infrastructure. United Nations Economic and Social Council [Online]. [Accessed 26.02.2019]. Available: http://unctad.org/meetings/en/SessionalDocuments/ecn162016d2_en.pdf

[32] Smart city technologies: what influences citizens ' choice? Mckinsey Center For Government [Online]. [Accessed 26.02.2019]. Available: https://www.mckinsey.com/ru/our-insights/smart-city-solutions-what-drives-citizenadoption-around-the-globe

[33] Shaping smarter and more sustainable cities: striving for sustainable development goals. The ITU-T Focus Group [Online]. [Accessed 26.02.2019]. Available: https://www.itu.int/dms_pub/itu-t/opb/tut/T-TUT-SSCIOT-2016-1PDF-E.pdf

[34] SMART REGION. The concept of construction in the Sverdlovsk region [Online]. [Accessed 26.02.2019]. Available: http://www.acexpert.ru/analytics/projects/umniy-region--smart-region-koncepciya-postroeniya-.html

[35] Program "Digital Kazakhstan" [Online]. [Accessed 26.02.2019]. Available: https://digitalkz.kz/wpcontent/uploads/2018/04/Digital-Kaz_ru.pdf

[36] "Smart city" Akkol [Online]. [Accessed 26.02.2019]. Available: https://www.kazpravda.kz/articles/view/umniigorod-akkol

[37] Almaty is awarded the highest award of the European forum of smart cities [Online]. [Accessed 26.02.2019]. Available: https://digitalkz.kz/ru/almaty-udostoen-vysshej-nagrady-evropejskogo-foruma-umnyh-gorodov/ 